\title{
https://doi.org/10.48009/2_iis_2005_57-63 \\ FACTORS THAT IMPACT MULTIMEDIA TRAINING APPLICATION DEVELOPMENT
}

\author{
Dr. Elaine Winston, Hofstra University, acserw@ hofstra.edu
}

\begin{abstract}
The proliferation of internet and communication technology has led to the rapid development of multimedia training applications that are delivered over corporate networks. Organizations that link these e-training systems to bottom-line business drivers may realize a distinct competitive advantage. On the other hand, ineffective e-training may result in unjustifiable costs to an organization. Given the high impact of e-training, a goal of this paper is to help IT personnel better understand "how we learn" and incorporate that knowledge in the development of high quality multimedia training applications. The paper discusses the results of a literature survey. It identifies key factors related to the development of high quality e-training applications. A framework is introduced to help clarify the relationship among key factors, application features, and pedagogical objectives. A sample of multimedia training applications and their evaluation is presented. Finally, managerial implications are suggested and future areas of study are identified.
\end{abstract}

Keywords: Multimedia, e-training, IT development, secondary data analysis

\section{INTRODUCTION}

The proliferation of internet and communication technology has led to the rapid development of multimedia training applications that are delivered over corporate networks $[1,29]$. Organizations use these e-training systems as an effective way to provide employees with immediate access to key information and subsequently achieve enterprisewide reliability and increased productivity [10].

By linking e-training to bottom-line business drivers, such as the introduction of new products, alignment of employee actions with organizational goals and compliance with new regulations, companies may realize a distinct competitive advantage $[1,16]$. On the other hand, ineffective etraining may result in employee mistakes, inaccurate decisions, and unjustifiable costs to an organization [23, 14]. Given the high impact of e-training, a goal of this paper is to help IT personnel better understand "how we learn" and incorporate that knowledge in the development of high quality multimedia training applications.

To explore concepts of multimedia training a literature survey was conducted. The paper discusses the results of the survey. First, it identifies key factors related to the development of high quality e-training applications. Second, it introduces a framework that helps to clarify the relationship among key factors, application features, and pedagogical objectives. A sample of multimedia training applications and their evaluation is presented. Finally, managerial implications are suggested and future areas of study are identified. 


\section{METHODOLOGY}

The primary source of this paper is a survey of literature on multimedia training application development (MTAD). The critical integration of information processing and pedagogical theories in IT development extended the survey to include studies on instructional design and cognitive engagement. The survey is based on scientific, managerial and professional literature from the early 1990's to the present. Previous studies have shown that the results of research activities reported in the literature are a viable source of secondary data $[8,19,27]$. The intelligent use of this secondary data plays a significant role in the accumulation of knowledge on multimedia training.

\section{FACTORS THAT IMPACT MULTIMEDIA TRAINING APPLICATION DEVELOPMENT (MTAD)}

Multimedia is characterized by the linkage of text, graphics, sound, video, virtual reality and the computer in such a way that the user is provided with nonlinear and essentially instantaneous access to these media $[12,9,17]$. It is this special characteristic that enables codification of realistic and relevant contexts and tasks, through which trainees develop understanding. Additionally, multimedia encourages an active and personalized learning approach by enabling users to work at their own speed and repeat exercises as needed to build usable knowledge.

Research in the area of multimedia technology and training is approached from various contexts: factor studies on interface and navigational design, case studies of actual training applications, and theoretical studies that connect pedagogical objectives to IT development. Data that is currently scattered throughout the literature is organized by combing these contexts and grouping similar concepts. Factors that were identified from this review are presented in four categories: (1) Content, (2) Dynamics, (3) Structure and (4) Presentation. Table 1 presents a relationship among key factors, application features and pedagogical goals.

\section{Content}

Content reflects both the descriptive and explanative information embedded in the multimedia application [23, 17]. Descriptive information refers to isolated facts. Explanative information represents organized facts that are connected through functional relationships.

Multimedia, by presenting multiple and complimentary representations of information, (e.g., presenting an image together with text or verbal descriptions), aids in the retention and recall of explanative information $[12,26]$. In this sense, e-training prepares employees for tasks that require a deep level of understanding in order to make accurate inferences and creatively solve problems. Conversely, some research suggests that multimedia does not improve the retention of descriptive information, which requires only text based representation $[17,15,20]$.

\section{Dynamics}

The dynamics of a training application is reflected in the graphical interface and employed through navigation. Navigation is the series of preplanned events/states linked together by different paths built into an application during development [12,21]. A key feature of 
multimedia training applications is an entertaining and intelligent guide that helps users reach their training goals using the shortest and least costly path [12].

Varying degrees of navigational freedom is provided in training applications. The literature identifies levels that range from non-interruptible and interruptible linear structures, to linked networks where the trainee generates individualized paths that are not predetermined by the IT developer and virtual visits where any modification is linked to the trainee's action $[29,12]$.

Table 1. Framework for Multimedia Training Application Development (MTAD)

\begin{tabular}{|c|c|c|c|}
\hline$\frac{\text { Factor }}{\text { (adapted }}$ & (adapted from Garzotto et al. 1995) & $\begin{array}{c}\text { Example Application } \\
\text { Features }\end{array}$ & Pedagogical Goals \\
\hline $\begin{array}{l}\text { Content } \\
\text { (C) }\end{array}$ & $\begin{array}{l}\text { The pieces of } \\
\text { information included in } \\
\text { the application. }\end{array}$ & $\begin{array}{l}\text { Descriptive and } \\
\text { explanative information; } \\
\text { Perceptive data. }\end{array}$ & $\begin{array}{l}\text { Explaining proper/improper } \\
\text { application of principles, } \\
\text { contrasting benefits with cos } \\
\text { and extending ideas to new } \\
\text { topics. }\end{array}$ \\
\hline $\begin{array}{l}\text { Dynamics } \\
\text { (D) }\end{array}$ & $\begin{array}{l}\text { How users interact with } \\
\text { individual pieces of } \\
\text { information. }\end{array}$ & $\begin{array}{l}\text { Graphical User Interface; } \\
\text { Navigation; Virtual } \\
\text { Environments. }\end{array}$ & $\begin{array}{l}\text { Providing instant feedback a } \\
\text { help and hands-on (interacti } \\
\text { exercises. }\end{array}$ \\
\hline $\begin{array}{l}\text { Structure } \\
\text { (S) }\end{array}$ & $\begin{array}{l}\text { The organization of data } \\
\text { and description of the } \\
\text { raw manipulation of } \\
\text { data, which the } \\
\text { application is capable of } \\
\text { performing }\end{array}$ & $\begin{array}{l}\text { Object oriented/relational } \\
\text { databases; Web and } \\
\text { streaming video servers; } \\
\text { Case-based reasoning. }\end{array}$ & $\begin{array}{l}\text { Achieving behaviorist and } \\
\text { constructivist models of } \\
\text { learning and building cognit } \\
\text { scaffolds. }\end{array}$ \\
\hline $\begin{array}{l}\text { Presentation } \\
\text { (P) }\end{array}$ & $\begin{array}{l}\text { How application content } \\
\text { and functions are shown } \\
\text { to the user. }\end{array}$ & $\begin{array}{l}\text { Include relational aspect of } \\
\text { media elements; } \\
\text { Visualization techniques; } \\
\text { apply design principles. }\end{array}$ & $\begin{array}{l}\text { Personalizing views of data } \\
\text { and delivering high quality } \\
\text { media to clarify and refine } \\
\text { information. }\end{array}$ \\
\hline
\end{tabular}

\section{Structure}

Structure concerns the organization of data and should correspond with pedagogical models. Generally, multimedia application development is influenced by two main learning models (1) behavioral and (2) constructivist. A behavioral approach refers to imitating and extending a role model's behavior [21]. Applications influenced by this approach will employ a hierarchical data structure that supports a step-by-step learning process and the division of contents by proficiency level. The structure will enable on demand delivery of demonstrations, drills, and reinforcement [9]. A constructivist learning model requires system features that encourage experimentation, hands-on practice, and questioning of concepts [21,25]. Data is structured to support hyperlinks, hypermedia and autonomous access to a range of pathways [27, 24]. 
Augmenting e-training with artificial intelligence technology provides a mechanism for storing an individual's learning record and offering personalized tutoring based on that record [29,24]. Virtual training environments and intelligent adaptive systems require implementation of a system that can reference information and create knowledge. The use of web and video streaming technology is necessary to help manage and provide access to complex knowledge repositories and video libraries used in e-training $[28,18]$.

\section{Presentation}

Multimedia training applications convey information through presentation, for example, a speech, animation, or video [12]. The presentation of information is partially controlled by IT developers through programming, compressing, and delivering media. The quality of the media will directly impact the clarity of the information passed on to the trainee [3]. Poor media quality, such as a user not able to see clearly what is going on in an animation or not being able to understand the spoken word in an audio recording, will impede learning [23].

The trainee also partially controls the presentation factor through, for example, interactive linking, drilling and visual techniques. Maps, gauges, and radar charts enhance the learning environment by enabling trainees to zoom in on selected information for details and provide integrated correlations among data [3]. Trainees, for example, who learn how to identify cases of fraud are prompted to highlight anomalies and look for broad patterns in heterogeneous data, which is available for presentation in multiple media formats. In virtual environments trainees are encouraged to manipulate views of an object such that extreme close-up examination of an object as well as observation from a great distance is feasible.

The format of media affects the trainees' thought processes and understanding of information. A presentation can be organized and constructed in different forms depending on the media, for example, textual words can represent plain text, hypertext or table and a graphical object can represent a map, flowchart or bar chart. Further, combining media contributes to the aesthetic and emotional presentation of information (i.e., sound is often used to offer a commentary that supplements the text) $[12,17,27]$.

\section{DISCUSSION}

Table 2 presents a sample of ten multimedia training applications and identifies whether or not factors were successfully implemented. Studies that refer to e-learning in university settings extend the results to applications that will prepare a future workforce. The evaluation of the etraining applications relied on a variety of approaches that include end-user surveys and interviews, organizational performance measurements, and direct observations. The categorization of factors that refer to content, dynamics, structure and presentation were supported by the data. These factors are judged positively or negatively.

A summary of the results is shown in Table 3. Five out of the ten training applications were rated low to mid quality due to problems with both content and structure. As reported, these applications did not include enough detailed and comprehensive information to achieve training goals. A better connection between data structure and pedagogical approaches might help IT developers improve their effectiveness in organizing and delivering comprehensive information to trainees. Case 6 indicates that the dynamics were insufficient and referred to a lack of 
flexibility. Case 2 noted a problem with presentation. The evaluators, who are case workers in a child protective agency, stated that the graphic presentation in the application did not match horrific real life experiences. It appears that even through simulation based training, human emotion, which impacts learning and how work is handled, is difficult to elicit.

Table 2. Evaluation of Sample e-Training Applications

\begin{tabular}{|c|c|c|c|c|c|c|c|}
\hline \multirow{2}{*}{$\begin{array}{c}\text { Case } \\
\#\end{array}$} & \multirow[t]{2}{*}{ Training } & \multirow{2}{*}{$\begin{array}{l}\text { Reference/ } \\
\text { Method of } \\
\text { Evaluation }\end{array}$} & \multicolumn{4}{|c|}{ Factors } & \multirow[t]{2}{*}{ Example Evidence } \\
\hline & & & $\mathbf{C}$ & $\mathbf{D}$ & $\mathbf{S}$ & $\mathbf{P}$ & \\
\hline 1 & Cardiology & $\begin{array}{l}\text { Gordon et al. } \\
\text { OQ, QP }\end{array}$ & + & + & + & + & $\begin{array}{l}\text { Accurate simulations effectively take the place of } \\
\text { lectures and demonstrations in the field. Applicability, } \\
\text { usability, and flexibility rated high. }\end{array}$ \\
\hline 2 & $\begin{array}{l}\text { Child } \\
\text { Protective } \\
\text { Services }\end{array}$ & $\begin{array}{l}\text { Satterwhite } \\
\text { and Schoech } \\
\text { OQ, Q }\end{array}$ & - & + & - & - & $\begin{array}{l}\text { Lacks sophistication in presenting casework process } \\
\text { and help/hints. Requires more realistic graphics and } \\
\text { balance and consistency of multimedia elements. }\end{array}$ \\
\hline 3 & $\begin{array}{l}\text { Data } \\
\text { Normalization/ } \\
\text { Internet Search } \\
\text { Engine }\end{array}$ & $\begin{array}{l}\text { Zhang } \\
\text { Q, QP }\end{array}$ & + & + & + & + & $\begin{array}{l}\text { Employs a virtual mentor and learning-centered } \\
\text { activities. }\end{array}$ \\
\hline 4 & $\begin{array}{l}\text { Environmental } \\
\text { Crisis } \\
\text { Management }\end{array}$ & $\begin{array}{l}\text { Stolk et al. } \\
\text { OQ,Q }\end{array}$ & - & + & - & + & $\begin{array}{l}\text { Requires more coverage of specific operational } \\
\text { procedures, difficult situations, and proactive } \\
\text { scenarios. Provides immediate feedback, access to any } \\
\text { situation at different levels, intelligence to maintain } \\
\text { path of learning, and game environment. }\end{array}$ \\
\hline 5 & Health care & $\begin{array}{l}\text { Fitzergerald } \\
\text { et al. } \\
\text { P }\end{array}$ & + & + & + & + & $\begin{array}{l}\text { Uses a high level structure, models can be accessed in } \\
\text { non-linear manner to meet different learning } \\
\text { preferences. }\end{array}$ \\
\hline 6 & $\begin{array}{l}\text { Information } \\
\text { Resource } \\
\text { Management }\end{array}$ & $\begin{array}{l}\text { Cappel and } \\
\text { Hayen } \\
\text { OQ, S }\end{array}$ & - & - & - & + & $\begin{array}{l}\text { Lack of exercises, flexibility, and interactivity to } \\
\text { reinforce learning. Multimedia aids in the } \\
\text { understanding of concepts. }\end{array}$ \\
\hline 7 & $\begin{array}{l}\text { Investment } \\
\text { Principles }\end{array}$ & $\begin{array}{l}\text { Stoney and } \\
\text { Oliver } \\
\mathrm{O}\end{array}$ & - & + & - & + & $\begin{array}{l}\text { Add random events to scenarios, increase problem } \\
\text { based learning to ensure higher order thinking, game } \\
\text { environment. }\end{array}$ \\
\hline 8 & Legal & $\begin{array}{l}\text { Bell } \\
\text { OQ, P }\end{array}$ & - & + & - & + & $\begin{array}{l}\text { Requires additional breadth and depth of subject and } \\
\text { hyperlink capability to reference material. Trainees are } \\
\text { not able to pass certification in the area. }\end{array}$ \\
\hline 9 & $\begin{array}{l}\text { Materials } \\
\text { Handling }\end{array}$ & $\begin{array}{l}\text { Heragu et al. } \\
\mathrm{I}, \mathrm{O}, \mathrm{S}\end{array}$ & + & + & + & + & $\begin{array}{l}\text { Provides goal scaffolding, extension of principles, } \\
\text { immediate feedback, and a virtual environment. }\end{array}$ \\
\hline 10 & Technical & $\begin{array}{l}\text { "Raytheon" } \\
\text { QP }\end{array}$ & + & + & + & + & $\begin{array}{l}\text { Provides detailed information on tasks and trouble } \\
\text { shooting. Usability and graphic design highly rated. } \\
\text { Very effective in reducing company costs. }\end{array}$ \\
\hline
\end{tabular}

Key: Evaluation: (+) successfully meets criteria, (-) does not successfully meet criteria Factors: $C=$ Content, $\mathrm{D}=$ Dynamics, $\mathrm{S}=$ Structure, $\mathrm{P}=$ Presentation Methodology: $\mathrm{I}=$ Interview, $\mathrm{O}=$ Observation, $\mathrm{OQ}=$ Open-ended questionnaire, $\mathrm{P}=$ Quantitative Performance, $\mathrm{Q}=$ Questionnaire, $\mathrm{QP}=$ Qualitative Performance, $\mathrm{S}=$ Survey 


\section{CONCLUSION}

This study offers some preliminary areas of importance for IT developers:

- Validate that content necessary for end-users to learn and master job requirements is complete and accurate.

- Apply pedagogical models to data organization so that content can be fully utilized.

Specifics on each study will be found by reading the source articles. Further study may unearth other factors essential to multimedia training development. Qualitative methodology could be used to further examine the relationship among content, structure, and high quality multimedia training application development. A study the researcher is currently working on is to identify the level of control that the IT developer has over each factor in comparison to the trainee's control over the factors during the use of the application.

Table 3. Summary of Results Based on Sample e-Training Application Cases

\begin{tabular}{lccccc}
\multicolumn{1}{c}{ Quality } & $\#$ & Content & Dynamics & Structure & Presentation \\
\hline High & 5 & 5 & 9 & 5 & 9 \\
Low - Mid & 5 & 5 & 1 & 5 & 1
\end{tabular}

\section{REFERENCES}

1. Allen, M. (December 2003). The Lessons of E-Learning, Optimize, (22).

2. Bell, C. (1997). Case Studies in Using Multimedia CBT for Court Tasks, Software, and Legal Research, Fifth National Court Technology Conference (CTC5), National Center for State Courts. September 1997.

3. Brath, R. \& Peters, M. (2005). Information Visualization for Business: Past and Future, DM Review, 40- 43.

4. Cappel, J. \& Hayen, R. (2004). Evaluating E-Learning: A Case Study. Journal of Computer Information Systems, 44(4), 49-56.

5. Fitzgerald, G., Nichols, P., \& Semrau, L. (1998). Training in Observation Skills for Health Care Professionals: Interactive Multimedia, American Educational Research Association Annual Meeting, April 1998.

6. Garzotta, F., Mainetti, L. \& Paolini, P. (1995). Hypermedia Design and Analysis and Evaluation Issues, Communications of the ACM, 38(8), 74-86.

7. Gordon, M., Issenberg, S., Mayer, J. \& Felner, J. (1999). Developments in the use of Simulators and Multimedia Computer Systems in Medical Education, Medical Teacher, 21(1), 32-36.

8. Gurbaxani, V. \& Mendelson, H. (1991). The Use of Secondary Analysis in MIS Research. The Information Systems Research Challenge: Survey Research Methods, 3. L. Kraemer (Ed.), Boston: Harvard Business School.

9. Hawa, M., Ortiz, A., Lario, F. \& Ros, L. (2002). Improving the Role Played by Humans in the Development of Enterprise Engineering and Integration Projects Through Training Based on Multimedia, International Journal of Computer Integrated Manufacturing, 15(4), 335344.

10. Hobbs, D. \& Moore, D. (1997). Multimedia Training Systems, Industrial Management \& Data Systems, 97(7/8), 259-263. 
11. Heragu, S., Graves, R., Malmborg, C., Jennings, S. \& Newman, D. (2003) Multimedia Tools For Use in Materials Handling Classes. European Journal of Engineering Education, 28(3), 375-393.

12. Huart, J., Kolski, C. \& Sagar, M. (2004). Evaluation of Multimedia Applications Using Inspection Methods: The Cognitive Walkthrough Case, Interacting with Computers, (16), 183-215.

13. IOMA (February 2004). How Raytheon Connects Training Programs and Results, Human Resources Department Management Report, 4(2/3).

14. Laine, L. (June 2003). Is Elearning Effective for IT training? $T+D, 57(6)$, 55-60.

15. Larkin, J. \& Simon H. (January 1987). Why a Diagram is (sometimes) Worth Ten Thousand Words, Cognitive Science, 11(1).

16. Levin, R. (1998). Train at the Speed of Change, Information Week, 06/08/98.

17. Lim, K. \& Benbasat, I., (2002). The Influence of Multimedia on Improving the Comprehension of Organization information, Journal of Management Information Systems, $19(1), 99-127$.

18. Lin, B. \& Hsieh, C. (2001). Web-based Teaching and Learner Control: A Research Review, Computers \& Education, (37), 377-386.

19. Lucas, H. (1991). Methodological Issues in Information Systems Research. The Information Systems Research Challenge: Survey Research Methods, 3, L. Kraemer (Ed.) Boston, MA: Harvard Business School.

20. Mayer, R. (1979). Can Advance Organizers Influence Meaningful Learning? Review of Educational Research, 49(2), 371-383.

21. Rodrigues, S. (2000). The Interpretive Zone Between Software Designers and a Science Educator: Grounding Instructional Multimedia Design in Learning Theory. Journal of Research on Computing in Education, 33(1).

22. Satterwhite, R. \& Schoech, D. (1995). Multimedia Training for Child Protective Service Workers: Results of Initial Development and Testing, Computers in Human Services, 12(1/2), 81-97.

23. Stein, C. \& Frolick, M. (2001).Ensuring Successful Development of Multimedia Computer Based Training (CBT), Information Systems Management, 36- 46.

24. Stolk, D., Alexandrian, D., Gros, B. \& Paggio, R. (2001). Gaming and Multimedia Application for Environmental Crisis Management Training, Computers in Human Behavior, (17), 627-642.

25. Stoney, S. \& Oliver, R. (1999). Can Higher Order Thinking and Cognitive Engagement be Enhanced with Multimedia, Interactive Multimedia Electronic Journal of Computer Enhanced Learning, 1(2), http://imej.wfu.edu/articles/1999/2/index.asp, (visited 1/16/05).

26. Syed, M. (2001). Diminishing the Distance in Distance Education, IEEE Multimedia, 8(3), $18-21$.

27. Thomas, J. (2003). A Rubric for The Evaluation of Interactive Multimedia and the Impact of Instruction of Students' Evaluations, Journal of Computer Information Systems, 43(4), 32-40.

28. Winston E. \& Dologite D. (1999). Achieving IT Infusion: A Conceptual model for Small Businesses, Information Resources Management Journal, 12(1), 6-38.

29. Zhang, D. (2004). Virtual Mentor and the Lab System - Toward Building an Interactive, Personalized and Intelligent E-Learning Environment, Journal of Computer Information Systems, 44(3), 35-43. 